\title{
Geç Tanı Konulan Bir Yassı Hücreli Karsinom Olgusu ve Literatürün Gözden Geçirilmesi
}

\author{
Delayed Diagnosis of a Case of Oral Squamous Cell Carcinoma and \\ Review of the Literature
}

\section{Olgun Topal}

Afyonkarahisar Sağlık Bilimleri Üniversitesi, Diş Hekimliği Fakültesi, Ağız Diş ve Çene Cerrahisi Anabilim Dalı, Afyon, Türkiye

\begin{abstract}
Özet: Ağız yassı hücreli karsinomu, ağız kanserlerinin en sık görülen şeklidir ve malign patolojilerin \% 90'nndan fazlasından sorumludur. Erken teşhis önemlidir. Ağız kanserlerinin tanısında gecikme, hasta, sağlık profesyonelleri veya sistemden kaynaklanabilir. 65 yaşındaki erkek bir hastada ağızda, gecikmiş yassı hücreli karsinom tanısı konulan bir olgu sunulmaktadır. Hasta sol üst çenenin arka bölgesinde yaklaşık 2 aydır süren ağız yarası ve ağrıdan dolayı tıp doktoruna gittiğini ve 10 gün üniversite hastanesinde yattığını belirtmiştir. İntraoral muayenesinde sol üst 8 numaralı dişin bukkal ve palatinal bölgesinde ülserasyonlu ve kanamalı hiperplastik mukoza saptandı. Ekstraoral muayenesinde sol tarafta hassas, fikse ve sert submandibular ve servikal lenf nodları belirlendi. Histopatolojik incelemede az diferansiye yassı hücreli karsinom tanısı geldi. Hasta cerrahi tedavi olmayı reddetti. Kemoterapi ve radyoterapi tedavisi görmeye başladı. Bir süre sonra hayatını kaybetti. Ağız yassı hücreli karsinomunun erken teşhis edilmesi zordur. Dolayısıyla, sağlık profesyonelleri ve hastaların iyileşmeyen ağız yaralarına şüpheli yaklaşmaları gerekmektedir.
\end{abstract}

Anahtar Kelimeler: Yassı hücreli karsinom, ağız kanseri, geç tanı, erken teşhis

\begin{abstract}
Squamous cell carcinoma is the predominant form of oral cancer and accounts for greater than $90 \%$ of malignant pathology. Early detection is an important criterion for achieving high cure rate. Delay in diagnosis consists of either patient delay or professional delay. Case report this article, we present a case report of 65-year-old male patient with oral squamous cell carcinomas with delayed diagnosis. He stated that the complaint of pain in maxillary left posterior region of the jaw for approximately 2 months. The patient's anamnesis revealed that during 10 days period, he had been to medical doctor in university hospital. In intraoral examination, the presence of ulcerated and haemorrhagic areas at the buccal and palatal sides were found. Extraoral examination revealed palpable, tender, non-mobile and firm submandibular and cervical lymph node on the left side. Histopathological examination revealed poorly differentiated squamous cell carcinoma. He refused to surgical treatment. He was treated by chemotherapy and radiotherapy after confirmation by incisional biopsy and died a few months after they. Oral squamous cell carcinoma can sometimes be difficult to early diagnose, So, health professionals and patients need to be aware that non-healing oral lesions, need to be considered as suspicious.
\end{abstract}

Keywords: Squamous cell carcinoma, oral cancer, delayed diagnosis, early diagnosis

ORCID ID of the author: O.T. 0000-0003-3550-8739 


\section{Giriş}

Oral kavite, dudakların vermilyon sınırından, sert ve yumuşak damakların ve sirkumvallat papillaların birleştiği yerle yaptığı hayali bir koronal düzlem içerisinde yer alır. Oral kavitede yedi anatomik alt bölge tanımlanmıștır bunlar; dudaklar, bukkal mukoza, alt ve üst alveoler kret tepeleri, sert damak, ağız tabanı, dil (ön üçte ikisi) ve retromolar üçgendir (1). Dünyada oral kavite ve dudak kanserlerinin yıllık insidans 350.000'den, mortalitesi de 170.000'den fazladır. Dünya çapında en sık görülen 17. malignitedir ve insidansı farklı coğrafi bölgeler arasında büyük ölçüde değişmektedir. Türkiye' de ise oral kavite ve dudak kanserlerinin y1llı insidansı 2.000'e, mortalitesi de 500'e yakındır. İnsidans yönünden 20., mortalite açısından da 25 . sırada bulunmaktadır (2). Oral kanserlerin yüzde doksanından fazlasını yassı hücreli karsinomlar oluşturur. Ülkeler arasında oral kavite kanser insidansında farklıl1klar görülmesi muhtemelen etnik ve sosyoekonomik faktörlerdeki farklılıkların yanı sıra tütün ürünlerinin kullanımının sıklığının bir sonucu olduğu bilinmektedir. Tütün kullanımının yanı sıra, alkol kullanımı, bağışıklık sisteminin zayıflaması, beslenme yetersizliği ve bazı insan papillomavirüsleri ile enfeksiyon risk faktörleri arasında yer almaktadır (3). Ulaşılabilir kaynaklarda hastanın veya sağlık profesyonellerinin oral kavitede yassı hücreli karsinomları geç teşhis ettiği belirtilmiştir. Tedavi seçenekleri, histopatolojik incelemeye bağlı olarak cerrahi, kemoterapi ve radyoterapinin bir kombinasyonunu içerir. Teknolojik gelişmelere rağmen oral kavite kanserlerinin tedavisinde son 30-40 y1lda uzun dönem sağkalım oranlarında değişiklik görülmemiştir (4). Oral kavite kanserlerinde erken tanı zor olmasına rağmen sağ kalımda çok önemli bir etkendir. Bu yüzden oral kavite kanserlerinin erken bulgu ve belirtilerinin belirlenmesinde ve önlenmesinde diş hekimlerine çok büyük görevler düșmektedir. $\mathrm{Bu}$ olgu sunumu ile oral kavitede yassı hücreli karsinomların tanısında hasta veya sağlık profesyonellerinden kaynaklanan gecikme yaşanabileceğinden, erken teşhisin tedavi için çok önemli olduğunun akılda tutulması amaçlanmıştır.

\section{Olgu Sunumu}

65 yaşındaki erkek hasta yaklaşık iki-üç aydan beri devam eden sol üst çenenin arka bölgesindeki ağız yarası ve ağrı șikayeti ile Afyonkarahisar Sağlık Bilimleri Üniversitesi Diş Hekimliği Fakültesi, Ağız Diş ve Çene Cerrahisi kliniğine başvurdu. Bu süre zarfında belirli aralıklar ile aile hekimine başvurduğunu ve antibiyotik, NSAİ ve gargara reçete edildiğini belirtmiştir. Şikayetleri azalmayınca üniversite hastanesinde doktora gittiğini ve 10 gün hastanede yattığını belirtmiştir. Hasta serviste yattığı süre boyunca damar yolundan antibiyotik ve ağı gargarası tedavisi uygulandığını belirtmiştir. İki yıl önce akciğer kanseri tedavisi gördüğünü iki yıllık izleminde herhangi bir sorun gözlenmediğini belirtmiştir. Hastanın kliniğimizde yapılan intraoral muayenesinde sol üst 8 numaralı dişinin bukkal ve palatinal bölgesinde ülserasyonlu ve kanamalı hiperplastik mukoza saptand1 (Resim 1). Ekstraoral muayenesinde de sol submandibular ve anterior servikal lenf nodlarında palpasyonda hassasiyet ve sertlik hissedildi. Hastanın radyolojik muayenesinde sol üst 8 nolu dişinin kök bütünlüğü net olarak izlenemedi (Resim 2). Lokal anestezi altında eksizyonel biyopsisi yapilan kitlenin histopatolojik incelemesinde; kesitlerde geniș ülserasyon alanları izlenmekteydi. Ülser dıșı alanlarda korunmuş epitel ile örtülü alanlarda subepitelyal alanda invaziv gelişim gösteren malign tümör görülmekteydi. Tümör nükleer pleomorfizmi belirgin, sık mitoz gösteren fokal keratinizasyon içeren atipik yassı epitel hücrelerinden oluşmaktaydı. Hücreler küçük ada ve tek hücre infiltrasyonu oluşturmaktaydı. Bu histopatolojik bulgular ile lezyona az diferansiye yassı hücreli karsinom tanısı konuldu. Tümörün klinik değerlendirilmesinde metastatik olabileceği düşünüldü. Hasta KBB kliniği ile beraber değerlendirildi. İlk etapta maksillektomi ve boyun diseksiyonu ameliyatı planland1. Hasta ameliyat olmayı reddetti. 
Onkoloji kliniği ile görüşüldü ve kemoterapi ile radyoterapi tedavisine başlandı. Teşhisin konulmasindan dört ay sonra hasta tedavileri devam ederken kaybedildi.

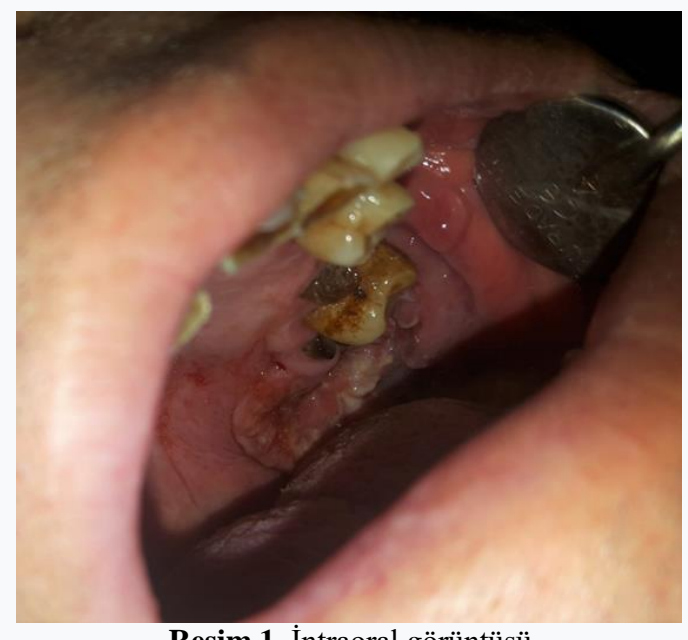

Resim 1. İntraoral görüntüsü

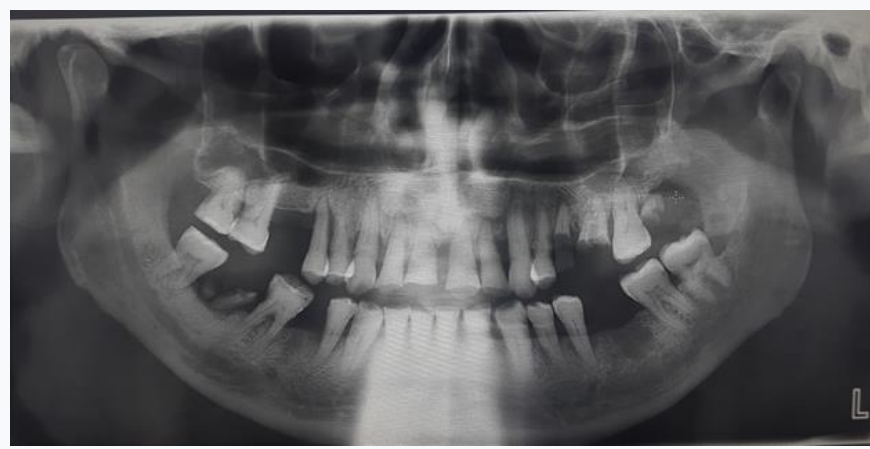

Resim 2. Panoromik röntgen

\section{Tartışma}

Ağız yassı hücreli karsinomları ağız mukozasının tüm yerleșim bölgesinde görülebilir. Kanserin erken teşhisi, hem tedavinin maliyetinin azalmasina hem de sağkalım oranının artmasına yol açar. 1. ve 2 . evredeki ağız kanseri hastalarının cerrahi veya radyoterapi tedavileri ile 2 yıl boyunca $\% 90$ oranında sağkalım görülürken, 3 . ve 4 . evre vakaların cerrahi radyoterepi ve kemoterapiye rağmen 2 yıllık süreçte $\% 45$ oranında sağkalım görüldüğü bildirilmiştir. Oral kanser hastalarının \% 40-60 arası geç aşamada teşhis edilmektedir ve geçen senelere rağmen son 40 yılda bu oranda azalma görülmemiştir (5). Toplumun ağız kanserlerinin erken belirtileri, semptomları ve risk faktörleri hakkındaki bilgi ve farkındalığı tanıda gecikmede önemli rol oynamaktadır.
Ulaşılabilir kaynaklarda tanı ve tedavideki gecikmeler üç bileşen altında gruplandırılmıştır (6). Hasta kaynaklı gecikme süresi tümorün özelliğine göre değişiklik gösterse de ortalama 5 ile 6 ay olarak bildirilmiştir. Çalışmalarda yaş cinsiyet sosyoekonomik durumların gecikmeyle ilişkisine bakılmıştır. Gecikmenin başlica nedenleri olarak hastaların bitkisel tedavileri denemeleri, kendiliğinden iyileşeceğini sanmaları ile korku, inkar veya sosyal sorumluluklarının yoğunluğu hasta gecikmesi ile ilişkili olabilecek faktörler olarak tanımlanmıştır. Diğer yandan, oral kanserler hakkında bilgi sahibi olan veya lezyonlarının kanser olabileceğini düşünen hastaların bir sağlık profesyonellerine gelme olasılıkları daha yüksektir $(7,8)$. 
Profosyonel gecikme her ne kadar hastanın hekime başvurmasından kesin tanıya ve tedaviye başlayana kadar olan süre olarak tanımlansa da hastanın ilk diş hekimine gelmesine rağmen, diş hekimlerinin diş ve dişetlerine odaklanması neticesinde veya hastalığın asemptomatik belirtilerinin gözden kaçırılması nedeniyle de prefosyonel gecikme yaşanabilmektedir. Çalışmalarda hasta gecikmesinin 3 aya, hekim gecikmesinin 6 aya ulaştığı vakalarda prognozun kötüye gittiği bildirilmiştir (9). Çalışmalarda profosyonel kaynaklı gecikmenin 5 ile 21 hafta arasında olduğu belirtilmiştir (10). Ağız kanserlerinin diğer kanserlere nazaran az görülmesinden dolayı tanı konulmasında veya ayırt edilmesinde güçlükler yaşanabilmektedir. Diş hekimlerinin yaklaşık $\%$ 13'ünün hastayı ilgili uzman hekime yönlendirdiği, \% 18'nin de hastaya antibiyotik reçete ettiği belirtilmiştir (11).

Sistem gecikmesinde hastanın, rahatsızlığını farketse bile sağlık kuruluşuna erişilebilirliği, sağlık kuruluşunun kullanılabilirliği ve maddi engeller sorumlu olabilmektedir.

\section{KAYNAKLAR}

1. Ward BB, Helman JI. Squamous Cell Carcinoma of the Oral and Maxillofacial Region. In: Oral and Maxillofacial Surgery: 3rd Edit [Internet]. 2018. p. 670-689.

2. Global Cancer Observatory [Internet]. [cited 2020 Apr 25]. Available from: https://gco.iarc.fr/

3. Priebe SL, Aleksejuniene J, Zed C, Dharamsi S, Thinh DH, Hong NT, et al. Oral squamous cell carcinoma and cultural oral risk habits in Vietnam. Int J Dent Hyg. 2010;8:159-68.

4. Raman P, Gayathri PS. Dentist's Delay or Dexterity to Diagnose the Deadly: A Clinicoradiological Series of Oral Malignancies Exhibiting Varied Presentations in the Tamil Nadu Rural Belt. Cureus. 2019;11:e4051.

5. Scully C, Kirby J. Statement on mouth cancer diagnosis and prevention. Br Dent J. 2014;216:3738.

6. Güneri P, Epstein JB. Late stage diagnosis of oral cancer: Components and possible solutions. Oral Oncol. 2014;50:1131-6.

7. Máximo MB, de Mendonça AC, Alves JF, Cortelli SC, Peruzzo DC DP. Peri-implant diseases may be associated with increased time loading and generalized periodontal bone loss: preliminary results. Int J Psychol Res. 2008;34:268-73.
Hastanın ağız boşluğunda meydana gelen değişimleri farketmesi gerek anatomik yoğunluktan gerekse de hastanın kendi kendine oral muayenesinin güçlüğünden dolay1 zordur. Dolayısıyla toplumun ve risk grubundaki bireylerin çeşitli yollarla (radyo televizyon vs.) farkındalıklarının artırılması tanıda ki gecikmeyi engellemek için bir yöntem olabilir. Ayrıca sağlık profesyonellerinin gecikme yapmaması için oral kavitede meydana gelen malign oluşumları ayırt edebilecek şekilde ve bir uzmana yönlendirmek için eğitilmesi gerekmektedir. Sistemsel olarak hastaların uzman hekime erişebilirliğini artırmak da gecikmeyi önlemede etkili bir yöntem olabilir.

\section{Sonuç}

Ağız kanserlerinin erken teşhis edilmesi açısından dikkatli bir anamnez ve rutin diş hekimi muayenesi önemlidir. Sağlık profesyonellerinin ve hastaların iyileşmeyen ağız yaralarına şüpheli yaklaşmaları ve şüpheli lezyon varlığında uzman diş hekimlerine yönlendirilmeleri gerekmektedir.
8. Peacock ZS, Pogrel MA, Schmidt BL. Exploring the reasons for delay in treatment of oral cancer. $J$ Am Dent Assoc. 2008 ;139:1346-52.

9. Paleri V, Welch A. Re: Relative importance of diagnostic delays in different head and neck cancers. Clin Otolaryngol. 2009;34:78-9.

10. Brouha XDR, Tromp DM, Koole R, Hordijk GJ, Winnubst JAM, de Leeuw JRJ. Professional delay in head and neck cancer patients: Analysis of the diagnostic pathway. Oral Oncol. 2007;43:551-6.

11. $\mathrm{Yu} \mathrm{T}$, Wood RE, Tenenbaum HC. Delays in diagnosis of head and neck cancers. J Can Dent Assoc. 2008;74:61. 